\title{
Spectrophotometric micro determination of drug promethazine hydrochloride in some pharmaceutical by chelating with Rhodium
}

\author{
Ashraf.S. AL-Ayash*
}

Fadhil Jasim*

Thamer zair*

Date of acceptance 2/4/2008

\begin{abstract}
The drug promethazine hydrochloride (PRZH) forms with rhodium (II) a colored chelate $(\lambda \max =472 \mathrm{~nm})$ complex at $(\mathrm{pH}=2.1)$ which is extractable with benzyl alcohol as organic solvent.

Under the appropriate experimental conditions a calibration plot was set up from which some analytical parameter were derived and deduced by regression. Standard addition procedure was also adopted. It has been estimated that the concentration of the drug PRZH to be $24.89 \mathrm{mg}$ per unit and $24.19 \mathrm{mg}$ per unit for both calibrations. Under optimal conditions, the developed method has been achieved the following characteristics:

LDR $\left(30-150 \mu \mathrm{g} \mathrm{ml}^{-1}\right)$ PRZH , RSD \% ( $\left.0.6-2.47\right)$, sandell sensitivity $(0.0844$ $\left.\mu \mathrm{g} . \mathrm{cm}^{-2}\right), \operatorname{LOD}\left(1.66 \mu \mathrm{gml}^{-1}\right)$, recovery \% ( $\left.100.74 \pm 1.34\right)$, Erel \% ( 0.74$)$. Stability constant $\left(6.4 \times 10^{5} \mathrm{M}^{-1}\right)$. The mole - ratio method (1: 1) approved that $\mathrm{PRZH}-\mathrm{Rh}$ (II) as a structure of the complex. The developed procedure has been adapted to analyze PRZH in various pharmaceuticals.
\end{abstract}

\section{Introduction:}

Promethazine, aphenothazine drug, is widely used as an antihistamine and a mild sedative ${ }^{[1]}$.

Various methods have been reported for the determination of promethazine hydrochloride these include spectrophotometry [2,3,4], HPLC [ 5,6 ], capillary zone electrophoresis ${ }^{[7]}$, titrimetry ${ }^{[8]}$.

In this work, a molecular spectrophotometric method for determination of drug promethazine hydrochloride (PRZH) in some pharmaceutical preparations by chelating with Rhodium (II) has been developed. The complex has a maximum absorption at (472 $\mathrm{nm})$. Benzyl alcohol was used as organic solvent for extraction of chelating complex. This method can be applied successfully to pharmaceutical preparation containing promethazine hydrochloride.

\section{Experimental Apparatus}

- all spectral and absorbance measurements were carried out on a shimadzu UV- Visible 160 a digital double - beam recording spectrometer using $1 \mathrm{~cm}$ silica cell.

- pH meter, Jenway 3020 .

\section{Reagents}

All chemicals used were of analytical reagent grade unless otherwise state, promethazine hydrochloride standard material was provided from the state company for drug industries and medical appliances samara - Iraq , phenergan drug was provide from the Arab pharmaceutical manufacturing Co.Ltd.,) sult - Jordan .

* Dept. of Chemistry, College of Science, University of Baghdad, Jadiryia , Baghdad, Iraq 
Promethazine hydrochloride Stock solution $\left(1000 \mu \mathrm{g} \mathrm{ml}^{-1}\right)$

A $0.1 \mathrm{gm}$ of PRZH was dissolved in water (DIW) and diluted to $100 \mathrm{ml}$ in a volumetric flask.

Rhodium Stock solution $\left(1000 \mu \mathrm{g} \mathrm{ml}^{-1}\right)$

A $0.2145 \mathrm{gm}$ of $\mathrm{Rh}\left(\mathrm{CH}_{3} \mathrm{COO}\right)_{2}$ was dissolved in $5 \mathrm{ml}$ of hydrochloride acid (3N) ,Diluted to100 $\mathrm{ml}$ in a volumetric flask with deionized water .

\section{Analytical Procedures}

\section{(A) Direct Calibration}

preparation of working calibration solutions in $\left(30-150 \mu \mathrm{g} \mathrm{PRZH} \mathrm{ml}{ }^{-1}\right)$ : A volume in range of $150-750 \mu \mathrm{l}$ of $1000 \mu \mathrm{g} \mathrm{PRZH} \mathrm{ml}^{-1}$ transferred to (250 ml) separating funnels, then $1 \mathrm{ml}$ of $250 \mu \mathrm{g} \mathrm{Rh} \mathrm{ml}^{-1}$ was added to each funnel and the $\mathrm{pH}$ of all solutions was adjusted to 2.1 using dil. $\mathrm{HCl}$ or $\mathrm{NaOH}$ solution. These solutions were set aside for $5 \mathrm{~min}$, and then diluted to $5 \mathrm{ml}$ with DW. Each solution was extracted with $3 \mathrm{ml}$ of benzyl alcohol after shaking for $3 \mathrm{~min}$, then the absorbance of organic layer was measured at $(\lambda \max =$ $472 \mathrm{~nm}$ ) against blank ( organic solvent ). The calibration graph was constructed and unknown PRZH concentration found by regression (Fig .1).

\section{(B) Standard additions}

An Appropriate equal volume of Drug samples solutions were add to 5 $\mathrm{ml}$ volumetric flask. An increase concentration of PRZH standard solution plus $1 \mathrm{ml}$ of $250 \mu \mathrm{g} \mathrm{Rh} \mathrm{ml}{ }^{-1}$ were added to each flask except one flask remain without standard addition . All solution was diluted to $5 \mathrm{ml}$ with DW after $\mathrm{pH}$ adjusted. The content of each flask was transferred to separating funnel. Then extracted processes and measurement with applied as mentioned in (A) the concentration of drug sample was obtained from the standard addition plot by regression (Fig 2).

\section{Results and Discussion}

\section{Absorption spectra}

I- drug stock solution

$0.25 \mathrm{ml}$ of $\left(1000 \mu \mathrm{g} \mathrm{ml}{ }^{-1}\right)$ promethazine hydrochloride standard solution, was transferred to $5 \mathrm{ml}$ volumetric flask, and diluted to the mark with water, $4 \mathrm{ml}$ of this solution , was transferred to absorption cell , then the absorption spectrum of this solution was measured in the region between 200 to $1100 \mathrm{~nm}$ using water as the reference. Fig (3) shows the two absorption maxima for the drug was 249 and $297 \mathrm{~nm}$.

\section{II - rhodium (II) stock solution}

Fig (4) shows the two absorption maxima for rhodium (II) by the application of the same procedure described in (I), was at 224 and 594 nm.

\section{III- orange - yellow complex of PRZH with Rhodium (II)}

The absorption spectrum of extracted complex was measured in the region (300 to 1100$)$ using the extracting solvent as the reference. Fig (5) shows that a wavelength maximum was $472 \mathrm{~nm}$.

\section{Optimization of Experimental Conditions}

\section{1-Effect of $p H$ Values}

The effect of $\mathrm{pH}$ on the formation of PRZH - Rh (II) complex is shown in Fig. (6); from which it appears that the best $\mathrm{pH}$ (2.1) for the formation of chelate complex occurs at value (2.1).

\section{2-Effect of Concentration of Rhodium (II)}

The concentration $\left(50 \mu \mathrm{g} \mathrm{ml}^{-1}\right)$ of rhodium ( II ) was found to be enough for the complete formation of chelating complex , Fig ( 7 ) .

3-Effect of Reaction Time 
Fig (8) refers that a reaction time of (4 $\mathrm{min}$ ) is enough for complete complex formation.

\section{4 - Effect of temperature}

The reaction of the rhodium with PRZH was very slow and it might be take exactly one hour, so we use the temperature as catalist to speed up the formation of the complex and inspit of using the temperature. It was found that the best temperature was $100^{\circ} \mathrm{c}$ is shown in Fig. (9).

5 -Organic Solvents used in the extraction

Since the method involves the measurement of complex in organic phase, it is necessary to use a solvent which will extract the chelate complex, but unreacted excess the rhodium (II) use. It was found that at $\mathrm{pH}(2.1)$ the $\mathrm{PRZH}$ is more soluble in water than in benzyl alcohol, but Rh (II) - PRZH is more soluble in benzyl alcohol than water.

\section{6- Effect of Extraction Time}

Fig (10) reveals that the complex of PRZH with rhodium (II), needed at least (1 min) of shaking to reach a state of equilibrium.<smiles>CC(CN1c2ccccc2Sc2ccccc21)N(C)C</smiles>

PRZH

\section{7- Effect of Phase Ratio}

An aqueous - to - organic phase of 5: 3 gives the highest extractability and highest absorbance, Fig (11).

\section{Extraction efficiency}

Table (1) shows molecular absorbance values for the extracted chelating complex of PRZH with rhodium (II) after the first and second extraction of the aqueous phase. The extraction efficiency (E \%) was found to be 93.37 and the distribution coefficient $(\mathrm{D}=23.47)$ was achieved.

\section{The molar ratio of ligand (L) to metal (M)}

The molar- ratio method at $\lambda \max =$ $472 \mathrm{~nm}$ showed that a 1: 1 complex was formed. Fig (12) shows the molar ratio of ligand: metal and the stability constant $(\mathrm{K})$ was calculated and equal to $6.4 \times 10^{5} \mathrm{M}^{-1}$.

\section{Structure of the complex}

Several techniques as FTIR, Molar ratio method have been used to elucidate the structure PRZH-Rh(II) complex formed at optimal conditions ,and from IR spectra and elemental analysis data, the following structure of the complex was suggested:

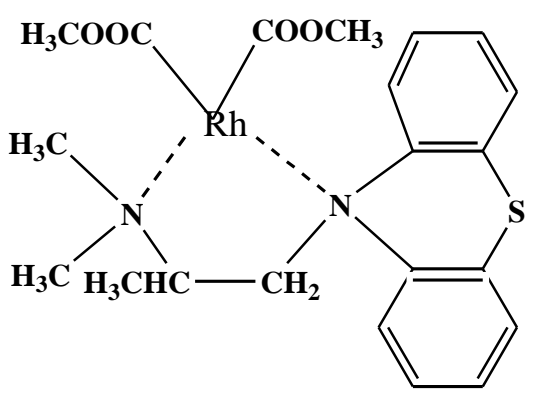

PRZH-Rh (II) 


\section{Calibration Graph}

Fig (1) shows a calibration graph of PRZH established by plotting the absorbance of complex vs. concentration and shows that beer's law is obeyed over the PRZH concentration of (30- 150 $\left.\mu \mathrm{gml}^{-1}\right)$ at wave length (472 $\left.\mathrm{nm}\right)$.

\section{Statistical Calculations}

All measurment can be characterized statistically. Table(2) shows the liner range of PRZH $\mathrm{Rh}$ ( II ) and detection limit, molar absorptivity $(\varepsilon)$, sandell sensitivity ( $\mathrm{S})$ and confidence limits for the concentration and the absorbance. Table (3) reveals that the test statistic $\mathrm{t}=134.12$ is higher than critical value (2.262) in regression analysis $(\mathrm{r}=0.9997)$. This means that the predications based on the estimated regression line $Y=0.0118 x+0.0127$ should be acceptable. Therefore, all concentration of PRZH in the analyzed sample was determined from this relationship.

Table (4) shows the accuracy test in term of recovery. Recovery $\%$ was shown to be acceptable and found to be $100.74 \pm 1.34$. Good precision as $E_{\text {rel }}$ of the method was achieved and found to be $0.74 \%$.

Standard additions procedure was also applied (Fig. 2) for the determination of PRZH complex and all the analytical performances were tabulated in table (5). The two samples of direct calibration and standard additions calculated was equal one, indicating the absence of interference effects and use of direct calibration is to be preferred.

\section{Analysis of PRZH in pharmaceutical preparations with rhodium}

Two procedures (direct calibration and standard additions) were used to determine PRZH in phenergan tablets at $\lambda=472 \mathrm{~nm}$. The results are shown in table (6) and table (7). Good agreement in concentration for both calibrations was obtained compared with the stated concentration of $25 \mathrm{mg}$ per unit.

\section{Conclusions}

This study has shown that the method described allows the rapid determination of promethazine. The analytical scheme of the proposed system is simpler than that of other conventional procedures. Moreover, it offers a higher sensitivity compared with other analytical methods and better recovery.

The analytical results obtained for the determination of PRZH in pharmaceuticals have shown good agreement with the given labeled quantity. The complex formed have stoichiometric ratio of 1 : 1 .

Table (1): absorbencies of complex after the first and second extraction

\begin{tabular}{|c|c|c|c|c|c|}
\hline $\begin{array}{c}P R Z H \\
\left(\mu g . m l^{-1}\right)\end{array}$ & $\begin{array}{c}R h(I I) \\
\left(\mu g . m l^{-1}\right)\end{array}$ & $p H$ & $\begin{array}{c}A_{1} \\
(E x . N o .1)\end{array}$ & $\begin{array}{c}A_{2} \\
(\text { Ex. No.2) }\end{array}$ & $\begin{array}{c}A_{o} \\
\text { Blank }\end{array}$ \\
\hline 70 & 50 & 2.1 & 0.793 & 0.039 & 0.009 \\
\hline
\end{tabular}


Table (2): analytical characteristics of result

\begin{tabular}{|c|c|c|c|c|c|c|c|}
\hline $\begin{array}{l}\lambda_{\max } \\
(\mathrm{nm})\end{array}$ & $\begin{array}{l}\text { Linearity } \\
\left(\mu g . \mathrm{ml}^{-1}\right)\end{array}$ & $\begin{array}{c}\text { D.L. }{ }^{* * * *} \\
\left(\mu g . \mathrm{ml}^{-1}\right) \\
(\mathrm{n}=11)\end{array}$ & $\begin{array}{l}\text { D.L.T.T } \\
\left(\mu g . m l^{-1}\right)\end{array}$ & $\begin{array}{c}S \\
\left(\mu g . \mathrm{cm}^{-2}\right)\end{array}$ & $\begin{array}{l}\text { Conf. Limit. } \\
\text { Conc. }\left(\mu g . \mathrm{ml}^{-1}\right) \\
95 \% \text { C.I }\end{array}$ & $\begin{array}{c}\text { Conf. Limit. } \\
\text { Abs. } \\
95 \% \text { C.I }\end{array}$ & $\begin{array}{c}\varepsilon \\
\left(L^{\prime} \mathrm{mol}^{-1} . \mathrm{cm}^{-1}\right)\end{array}$ \\
\hline 472 & $30-150$ & 1.66 & 1.77 & 83565.40 & $69.45 \pm 1.05$ & $0.832 \pm 0.028$ & $3.8 \times 10^{3}$ \\
\hline
\end{tabular}

\section{**** Experimental}

** Theoretical

Table (3) : Regression equation, correlation coefficient $(r)$ two tailed $t$-test and confidence limit for the slope for the intercept at $95 \%$ confidence level and $(n-2)$ degree of freedom for the calibration graph.

\begin{tabular}{|c|c|c|c|c|c||}
\hline $\begin{array}{c}\text { Regre. } E q . \\
Y=B X+\boldsymbol{A}\end{array}$ & $\begin{array}{c}\text { Corr. } \\
\text { Coef. } \\
(\boldsymbol{r})\end{array}$ & $\begin{array}{c}\text { t- test } \\
\text { statistic }\end{array}$ & $\begin{array}{c}\text { Tabulated } \text { - test } \\
\text { two tailed }(\boldsymbol{n}-2) \\
95 \% \text { C.I }\end{array}$ & $\begin{array}{c}\text { Conf. Limit. for } \\
\text { the slope } \boldsymbol{b}+\boldsymbol{t}_{\text {sb }}\end{array}$ & $\begin{array}{c}\text { Conf. Limit for } \\
\text { the intercept } \\
\boldsymbol{a}+\boldsymbol{t}_{\boldsymbol{s} a}\end{array}$ \\
\hline $\mathrm{Y}=0.0118 \mathrm{X}+0.0127$ & 0.9997 & 134.124 & 2.262 & $0.0077 \pm 0.0027$ & $0.234 \pm 0.223$ \\
\hline
\end{tabular}

Table (4): shows the relative standard deviation $R S D \%, E_{\text {rel\% }}$, recovery $R e c \%$

\begin{tabular}{|c|c|c|c|c|c|c||}
\hline $\begin{array}{c}\text { Amount of } \\
\text { PRZH taken } \\
\left(\mu g . \text { ml }^{-1}\right)\end{array}$ & $\begin{array}{c}\text { Amount of } \\
\text { PRZH found } \\
\left(\mu g . \mathbf{m l}^{-1}\right)\end{array}$ & \%Rec. & \%Erel. & $\begin{array}{c}\text { \%RSD } \\
\boldsymbol{n}=\mathbf{5}\end{array}$ & $\begin{array}{c}\text { Mean } \\
\text { \%Rec. }+ \text { S.D }\end{array}$ & $\begin{array}{c}\text { Mean } \\
\text { \%Erel. }\end{array}$ \\
\hline 40 & 40.57 & 101.11 & 1.1 & 1.42 & $100.74 \pm 1.34$ & 0.74 \\
\hline 80 & 80.27 & 100.33 & 0.335 & 0.60 & - & - \\
\hline 120 & 120.95 & 100.79 & 0.79 & 2.47 & - & - \\
\hline
\end{tabular}

Table (5): shows regression equation, correlation coefficient $(r)$ two tailed t-test and confidence limit for $X$-Value obtained $\left(X_{E}\right)$ at $95 \%$ confidence limit and $(n-2)$ degree of freedom for the standard additions calibration graph, recovery $R e c \%, E_{\text {rel } \%}$.

\begin{tabular}{|c|c|c|c|c|c|c|}
\hline $\begin{array}{c}\text { Regre. } E q . \\
Y=B X+A\end{array}$ & $\begin{array}{l}\text { Corr. } \\
\text { Coef. } \\
(r)\end{array}$ & $\begin{array}{c}t \text { - test } \\
\text { statistic }\end{array}$ & $\begin{array}{c}\text { Tabulated } t \text { - test two } \\
\text { tailed } n-2 \\
95 \% \text { C.I }\end{array}$ & $\begin{array}{c}\text { Conf. Limit for } \\
\begin{array}{c}x \text {-value } \\
X E+t s X E\end{array} \\
\end{array}$ & $\begin{array}{l}\text { Rec. } \\
(\%)\end{array}$ & $\begin{array}{c}\text { Erel. } \\
(\%)\end{array}$ \\
\hline $\mathrm{Y}=0.0121 \mathrm{X}+0.3049$ & 0.9992 & 63.194 & 2.447 & $28.22 \pm 0.2849$ & 94.06 & -5.9 \\
\hline
\end{tabular}

Table (6): determination PRZH in sample of pharmaceutical preparation by direct calibration and standard additions.

\begin{tabular}{|c|c|c|c|c|c|c|}
\hline $\begin{array}{c}\text { Name of } \\
\text { pharmaceutical }\end{array}$ & $\begin{array}{c}\text { Type of } \\
\text { Preparation }\end{array}$ & $\begin{array}{c}\text { Stated } \\
\text { concentration } \\
\text { (mg per unit) }\end{array}$ & $\begin{array}{c}\text { Found } \\
\text { (direct calb.) } \\
\text { (mg per unit) }\end{array}$ & \%Erel. & $\begin{array}{c}\text { Found } \\
\text { (st. add. calb.) } \\
\text { (mg per unit) }\end{array}$ & \%Erel. \\
\hline Phenergan & Tablets & 25 & 24.89 & -0.44 & 24.19 & -3.3 \\
\hline
\end{tabular}

\begin{tabular}{|c|c|c|c|c|c|c|}
\hline $\begin{array}{c}\text { Amount of } \\
\text { PRZH taken } \\
\left(\mu g . m L^{-1}\right)\end{array}$ & $\begin{array}{c}\text { Amount of } \\
\text { PRZH found } \\
\left(\mu g . \mathrm{mL}^{-1}\right)\end{array}$ & $\begin{array}{l}\text { Rec. } \\
(\%)\end{array}$ & $\begin{array}{c}\text { Erel. } \\
(\%)\end{array}$ & $\begin{array}{c}R S D \\
(\%) \\
(n=5) \\
\end{array}$ & $\begin{array}{c}\text { Mean } \\
\text { Rec.\%+S.D }\end{array}$ & $\begin{array}{c}\text { Mean Erel. } \\
(\%)\end{array}$ \\
\hline 45 & 44.96 & 99.91 & -0.088 & 1.2 & $98.8 \pm 3.04$ & -0.78 \\
\hline 75 & 74.3 & 99.06 & -0.93 & 1.4 & - & - \\
\hline
\end{tabular}




\begin{tabular}{|l|l|l|l|l|}
105 & 103.6 & 98.6 & -1.33 & 2.25 \\
\hline
\end{tabular}

Table (7): shows the $R S D \%, E_{\text {rel }}$, recovery Rec\% the calibration graph.

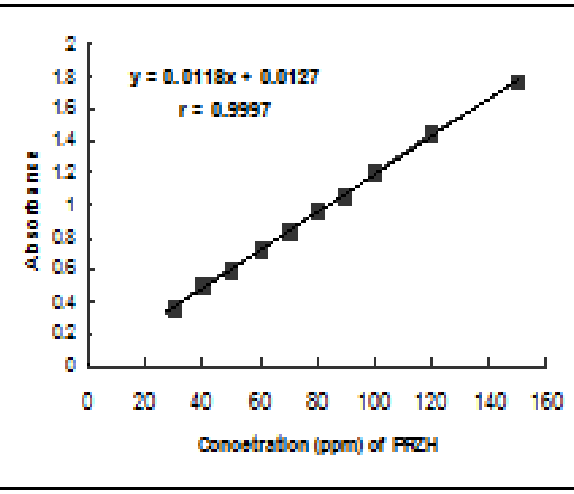

Fig1: Calibration graph for the determination of $\mathrm{PRZH}-\mathrm{Rh}$ ( II)

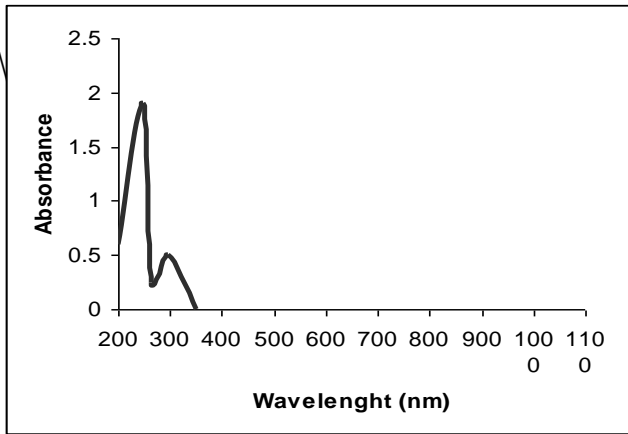

Fig3: absorption spectrum of PRZH

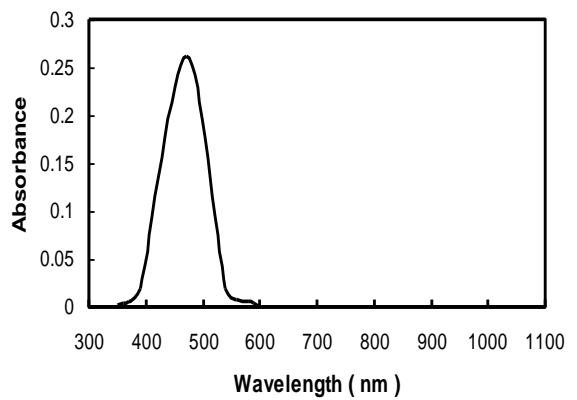

Fig5: absorption spectrum of complex PRZH - Rh (II )

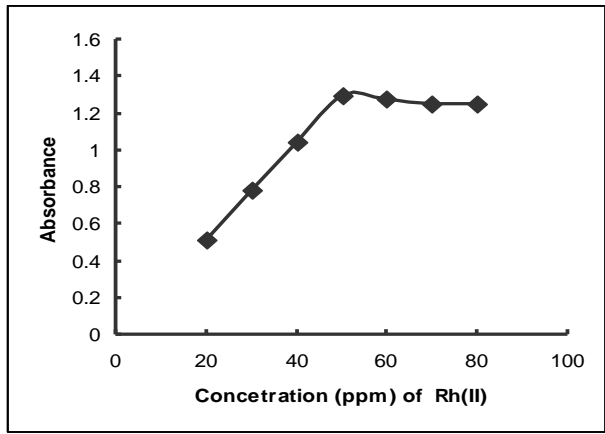

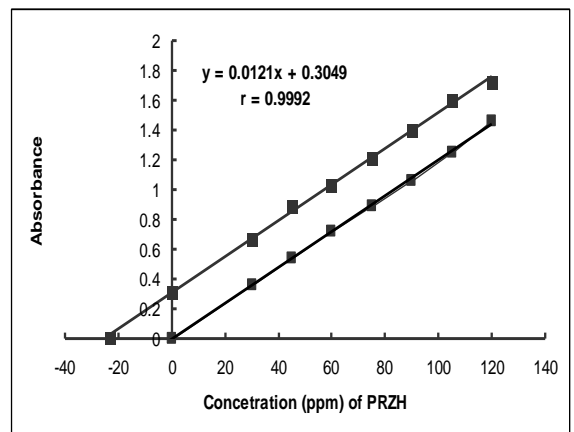

Fig.(2): Determination of PRZH s procedures in pharmaceuticals by using direct and standard additions

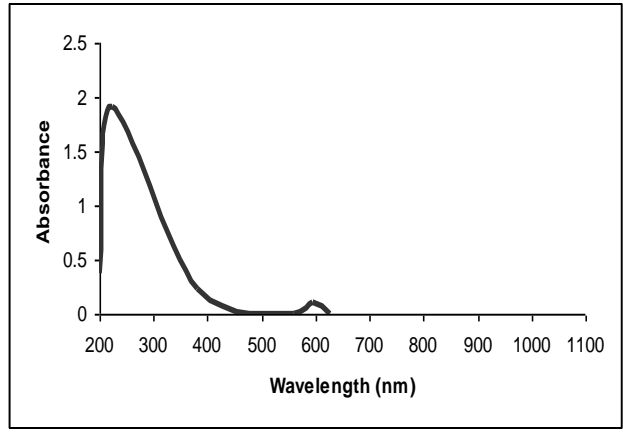

Fig4: absorption spectrum of Rh (II)

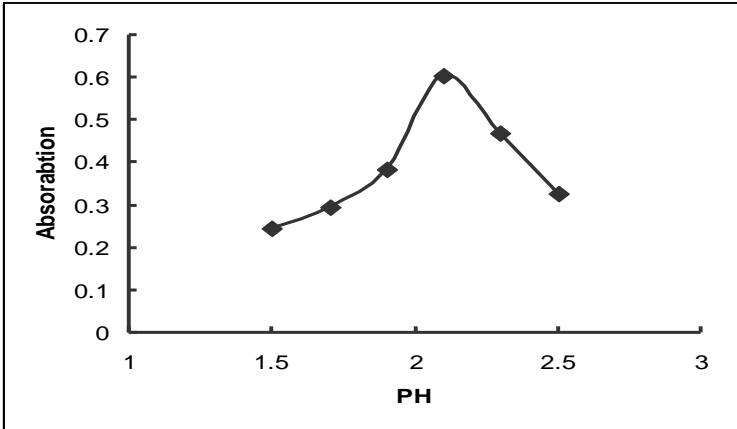

Fig.(6): Effect of $\mathrm{pH}$

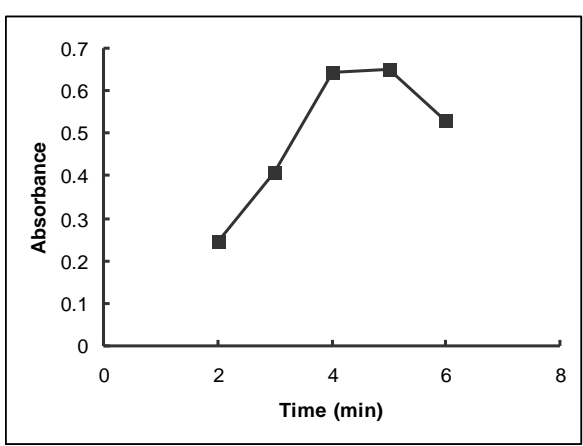


Fig. (7): Effect of Concn. of Rhodium on the determination of PRZH

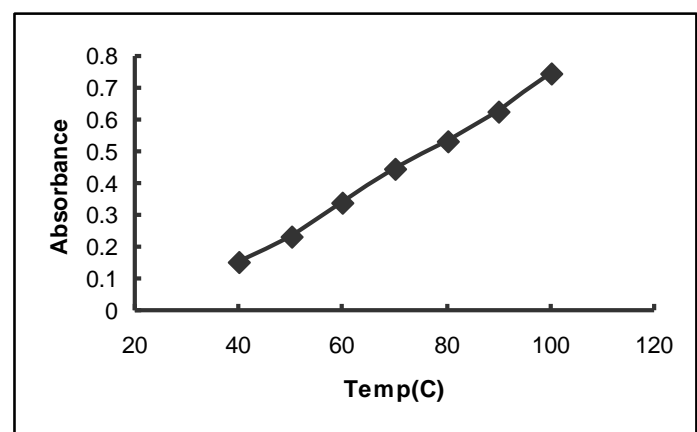

Fig.(9): Effect of temperature

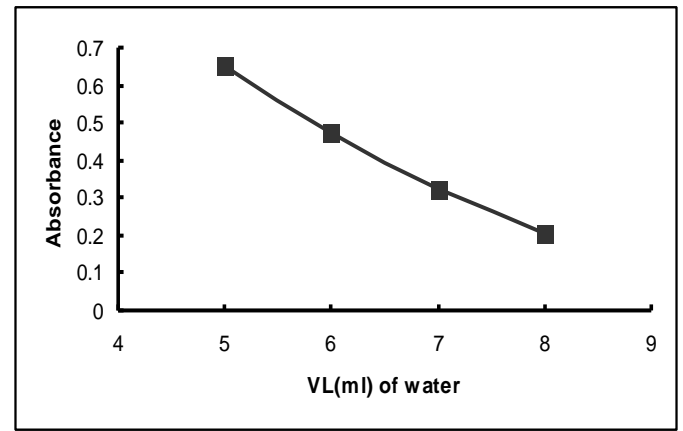

Fig.(11): Effect of phase ratio
Fig.(8): Effect of reaction time

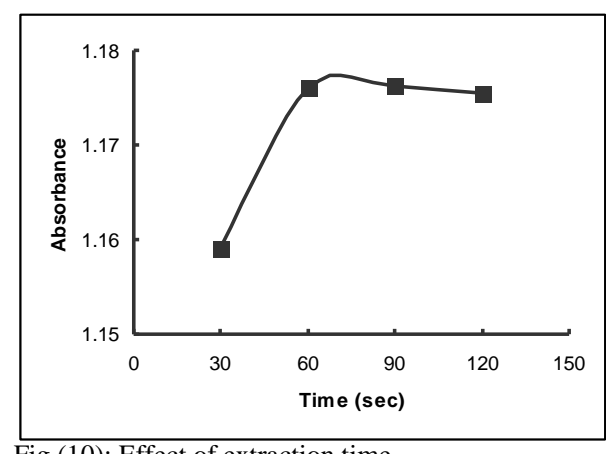

Fig.(10): Effect of extraction time

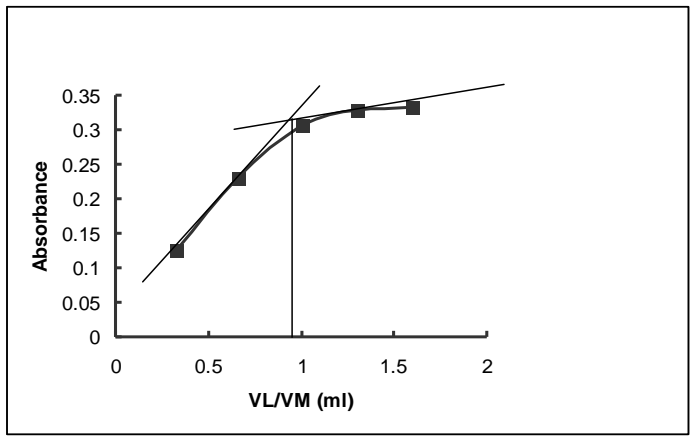

Fig.(12): Molar ratio plot, PRZH - Rh ( II )
References

1. Howard, C. A.; Loyd, V. A.; Nicholas, G. P. 1990. "Pharmaceutical dosage forms and Drug Delivery Systems", Lippincott Williams \& Wilkins Publishers, pp.51.

2. Farhadi, K., Savojbolaghi, A. K., Maleki, R., 2003. Study of Reactions of Triiodide and Alizarin Red $S$ with Some Important Phenothiazines. Development of an in direct Titrimetric and a Spectrophotometric Method for the Assay of Phenothiazine Derivatives .J. Chin. Chem. Sos., 50 (1):153 159.

3. Nagaraja, P., Dinesh, D. N., Made Gowda ,M. N., and Rangappa, S., 2000 Simple Spectrophotometric Determination of Some
Phenothiazine Drugs in Pharmaceutical Samples .Anal. Sci., 16(11): 1127 -1131.

4. Basavaiah, K., Srilatha, Swanmy, J.M., and Krishnamurthy, G., 2000. Spectrophotometric Determination of Promethazine Hydrochloride with Eosin Y. Anal.lett., 33 (1): 4355.

5. Tesarova, E., Bosakova, Z., 2003. The factor affecting the enantiomeric resolution and racemisation of oxazepam, lorazepam and promethazine on macrocyclic antibiotics-bonded chiral stationary phases .Chem.Anal., 48( 3 ): 439 - 451 .

6. Bosakova, Z., Klouckova, I., Tesarova, E., 2002. Study of the stability of promethazine enantiomers by liquid 
chromatography using a

pharmaceutical formulations using vancomycin-bonded chiral a CZE method .Anal. Chim.Acta, stationary phase .J.Chromatogr. B., $770(1-2): 63-69$. 535(1): $101-108$.

7. Lara, F.J., García-Campańa, A. M., and Alés-Barrero , F., 2005. Determination of thiazinamium, promazine and promethazine in

8. Gilpin, R.K and Pachla, L.A., 1999. Pharmaceuticals and Related Drugs. Anal. Chem., 71(12):217233.

\section{التقدير الطيفي للاواء هيدروكلوريد البروميثازين في بعض المستحضرات الصيدلانية باستخدام فلز الروديوم كوسيط}

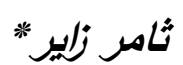

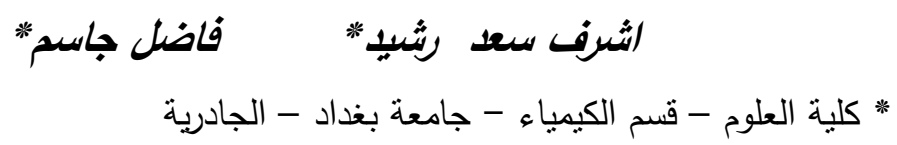

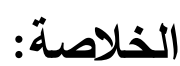

يتضمن البحث استحداث طريقة تحليلية جديدة في تقدير المركب الدوائي هيدروكلوريد بروميثازين (المستعمل في علاج الحساسية والتقيؤ) في الدواء فنركان بطريقة الامتصاص الطيفي الجزيئي حيث تم تقدير الدواء بتكوين المعقد PRZH-Rh(II) بعد دراسة الظروف العملية المتلى: الرقم الهيدروجيني(2.1=PH) وتركيز الأيون (Rh(II)) (50ميكروغرام.مل-1) ونسبة الطور المائي إلى العضوي (3:5) وزمن التفاعل (4-5) دقائق لإكمال التفاعل قبل عملية الاستخلاص، أما افضل زمن للاستخلاص فهو دقيقه واحده لاستخلاص المعقد

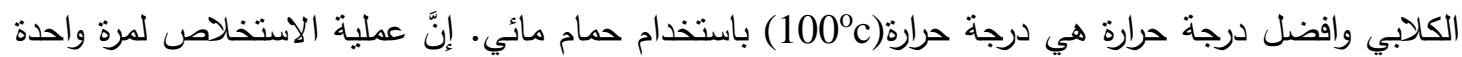

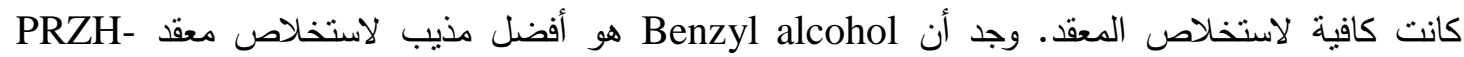
Rh(II)

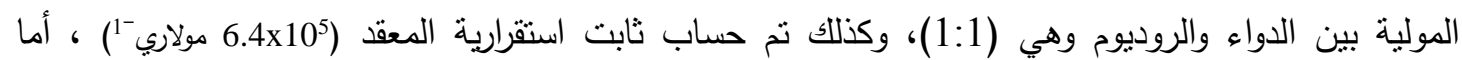
مديات التركيز في تعيين الدواء فكانت (30- 150 ميكروغرام.مل-1) وحد الكثف (1.66 ميكروغرام.مل-1)

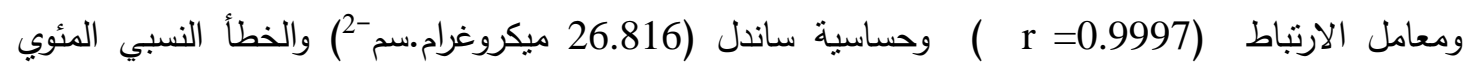
(0.74\%) والدقة (0.60-2.74\%) والاستردادية (1.34 \& 100.74). كما تم تعيين الدواء في المستحضر الصيدلاني بالطريقة المباشرة وطريقة إضافات القياس. 